OPEN ACCESS

Edited by:

Minbin Yu,

Sun Yat-sen University, China

Reviewed by:

Xinping Yu,

Sun Yat-sen University, China Anand Marya,

University of Puthisastra, Cambodia

*Correspondence:

Xiangwen Shu

snailsxw@163.com

Specialty section:

This article was submitted to

Pediatric Otolaryngology,

a section of the journal

Frontiers in Pediatrics

Received: 23 October 2020 Accepted: 26 April 2021 Published: 21 May 2021

Citation:

Gao L, Gao Y, Hong F, Zhang P and Shu X (2021) Assessment of Foveal Avascular Zone and Macular Vascular

Plexus Density in Children With

Unilateral Amblyopia: A Systemic

Review and Meta-Analysis.

Front. Pediatr. 9:620565

doi: 10.3389/fped.2021.620565

\section{Assessment of Foveal Avascular Zone and Macular Vascular Plexus Density in Children With Unilateral Amblyopia: A Systemic Review and Meta-Analysis}

\author{
Lei Gao ${ }^{1}$, Yang Gao ${ }^{1}$, Fengrong Hong ${ }^{2}$, Peng Zhang ${ }^{1}$ and Xiangwen Shu ${ }^{1 *}$ \\ ${ }^{1}$ Department of Ophthalmology, Jinan 2nd People's Hospital, Jinan, China, ${ }^{2}$ Department of Ophthalmology, Linqing People's \\ Hospital, Linqing, China
}

Purpose: To examine the quantitative measurements of OCTA in children with amblyopia using the meta-analysis methodology.

Methods: PubMed, Embase, and Cochrane library were searched for available papers up to March 2021. Weighted mean differences (WMD) were used to compare the retina parameters between the eyes with amblyopia and the contralateral eyes or healthy control eyes.

Results: Twelve studies were included. When considering the parafovea, the microvessel density was reduced in amblyopic eyes compared with healthy control eyes in the superficial capillary plexus (SCP) in $6 \times 6$ volume scan $(\mathrm{WMD}=-2.12,95 \% \mathrm{Cl}$ : $-3.24,-0.99)$ but not SCP in $3 \times 3$ volume scan ( $\mathrm{WMD}=-1.43,95 \% \mathrm{Cl}:-2.96,0.11)$. In the deep capillary plexus (DCP), amblyopia did not decrease vessel density in the 6 $\times 6$ volume scan $\left(\mathrm{WMD}=-2.22,95 \% \mathrm{Cl}:-5.86,1.42 ; I^{2}=79.6 \%, P=0.008\right)$, but a difference was observed in the whole eye $3 \times 3(\mathrm{WMD}=-1.95,95 \% \mathrm{Cl}:-3.23,-0.67$; $\left.R^{2}=27.5 \%, P=0.252\right)$. There were no significant differences in the foveal avascular zone area and foveal thickness between amblyopic eyes and healthy control eyes. There were no significant differences in microvessel density, foveal avascular zone area, and foveal thickness between amblyopic eyes and fellow eyes.

Conclusion: According to OCTA, amblyopic eyes had lower vessel density in parafoveal SCP and DCP compared with healthy control eyes, but not compared with fellow eyes. There were no significant differences regarding the foveal avascular zone area and foveal thickness between amblyopic and non-amblyopic eyes.

Keywords: fovea, macula, angiography, amblyopia, unilateral, meta-analysis, tomography, optical coherence

\section{INTRODUCTION}

Amblyopia is defined as a reduction in best-corrected visual acuity (2-line difference between the two eyes) secondary to neurological deficits in visual output caused by abnormal brain stimulation during critical periods of visual development (1-3). It is usually unilateral and is the most common cause of vision loss and mononuclear blindness in children. It remains the most common cause of 
preventable vision loss in children (4). The worldwide prevalence is $1-5 \%$, and the prevalence in North America is $2-4 \%(2,3)$.

In animal models of amblyopia, fewer ganglion cells project to the central visual nuclei (5), and it has been suggested that the postnatal process of ganglion cell reduction is affected by amblyopia and should result in a thicker circumpapillary retinal nerve fiber layer (6). A meta-analysis of optical coherence tomography (OCT) studies revealed that a thicker foveola was found in amblyopic eyes compared with normal eyes (7). On the other hand, it is unknown whether this thicker fovea is associated with changes in blood flow or microvessel density.

OCT angiography (OCTA) is a relatively new and noninvasive imaging technique that uses motion control contrast imaging to obtain high-resolution volumetric blood flow information and generate angiographic images of the retina and choroid (8). The advantages of OCTA over the traditional fluorescein and indocyanine-green angiography are its fast acquisition time and non-invasiveness $(9,10)$. In addition, it provides quantitative measurements (11). It can be used to assess retinal diseases, glaucoma, and uveitis $(9,10)$. Importantly, OCTA can provide quantitative assessments of the superficial capillary plexus (SCP) and deep capillary plexus (DCP) (12). Some studies examined the use of OCTA for amblyopic eyes, but the results are inconsistent, and no meta-analysis is available to synthesize the quantitative measurements of OCTA in children with amblyopia.

Therefore, the aim of the present meta-analysis is to examine the quantitative measurements of OCTA in children with amblyopia. The results could provide a firmer basis for the use of OCTA for the management of amblyopia.

\section{METHODS}

\section{Study Selection}

This meta-analysis was conducted according to the Preferred Reporting Items for Systematic Reviews and Meta-Analyses (PRISMA) guidelines. The study eligibility criteria were: (1) children with amblyopia in one eye as the case group, compared with the contralateral eyes or healthy control eyes; (2) quantitative measurement of the foveal avascular zone and macular vascular plexus density using OCTA; (3) language limited to English; and (4) the outcomes could be extracted.

PubMed, Embase, and Cochrane library were searched for available papers up to March 2021 using the MeSH terms and key words pertinent to "amblyopia" and "optical coherence tomography angiography."

\section{Data Extraction and Quality Assessment}

The selection and inclusion of studies were performed in two stages by two independent reviewers (Lei Gao and Xiangwen Shu). This included, first, the analysis of the titles and abstracts, followed by the full texts. Any disagreements were resolved by a third reviewer (Peng Zhang).

Data, including names of authors, publication year, study design, sample size, type of amblyopia, OCTA algorithm, and spherical equivalent, were gathered with a structured data collecting form. The observational studies were evaluated according to the Newcastle-Ottawa scale (NOS) $(13,14)$.

\section{Statistical Analysis}

All analyses were performed using STATA SE 14.0 (StataCorp, College Station, Texas, USA). Weighted mean differences (WMD) and corresponding 95\% confidence intervals (CIs) were used to compare the retina parameters between the eyes with amblyopia and the contralateral eyes or healthy control eyes. Statistical heterogeneity among these studies was calculated using Cochran's Q-test and the $I^{2}$ index. Q-test with $P<0.10$ and $I^{2}>$ $50 \%$ indicated high heterogeneity, and the random-effects model was then used; otherwise, the fixed-effects model was used. The publication bias was analyzed using funnel plots. $P$-values $<0.05$ were considered statistically significant.

\section{RESULTS}

\section{Search Process}

A total of 95 entries were retrieved from PubMed and Embase. After removing duplicates, 68 titles and abstracts were screened. After excluding the irrelevant papers and invalid paper types, 15 full-text papers were reviewed. One was excluded for no available data and two for inappropriate outcomes. Therefore, 12 studies were included in the present meta-analysis (15-26) (Figure 1 and Table 1). There were eight cross-sectional studies $(15,16,18-$ $20,23,25,26)$, one longitudinal study (17), one cohort study (24), one case-control study (22), and one undefined (21). A total of 1,744 patients were included (range, 12-1,075/study). Table 2 presents the quality of the studies according to the NOS. All 12 studies were of high quality.

\section{Macular Vessel Density in Amblyopic Eyes Compared With Healthy Control Eyes}

In the SCP, when considering the whole eye in $6 \times 6$ volume scan, amblyopia decreased the vessel density (WMD $=-2.12$, $95 \% \mathrm{CI}:-3.24,-0.99)$, but not when considering the whole eye in $3 \times 3$ volume scan (WMD $=-1.43,95 \% \mathrm{CI}:-2.96,0.11)$. Heterogeneity was not observed for the $6 \times 6$ analysis $\left(I^{2}=\right.$ $0.0 \%, P=0.920)$, but there was heterogeneity for the $3 \times 3$ volume scan $\left(I^{2}=59.3 \%, P=0.085\right)$. No impacts were observed when considering the fovea $3 \times 3$ volume scan $(\mathrm{WMD}=-0.92$, $95 \% \mathrm{CI}:-3.90,2.07)$. Heterogeneity was observed $\left(I^{2}=81.2 \%, P\right.$ $=0.001)$. When considering the parafovea $3 \times 3$, the microvessel density in the SCP was reduced in amblyopic eyes (WMD = $-1.45,95 \% \mathrm{CI}:-2.54,-0.36)$. Heterogeneity was not observed $\left(I^{2}=39.6 \%, P=0.174\right)$ (Figure 2A). In the subgroup analyses, and impact of anisometropia was observed on the whole eye $(\mathrm{WMD}=-2.40,95 \% \mathrm{CI}:-4.17,-0.63)$. Similar effects were observed for mixed amblyopia (WMD $=-1.92,95 \% \mathrm{CI}:-3.38$, $-0.47 ; I^{2}=0.0 \%, P=0.979$ ) (Supplementary Figure 1A). No impact was observed at the fovea level. At the parafovea level, mixed amblyopia affected the microvessel density (WMD = -1.96 , 95\%CI: $\left.-2.84,-1.08 ; I^{2}=0.0 \%, P=0.382\right)$, but not anisometropia $(\mathrm{WMD}=-0.40,95 \% \mathrm{CI}: 1.92,1.12)$. 


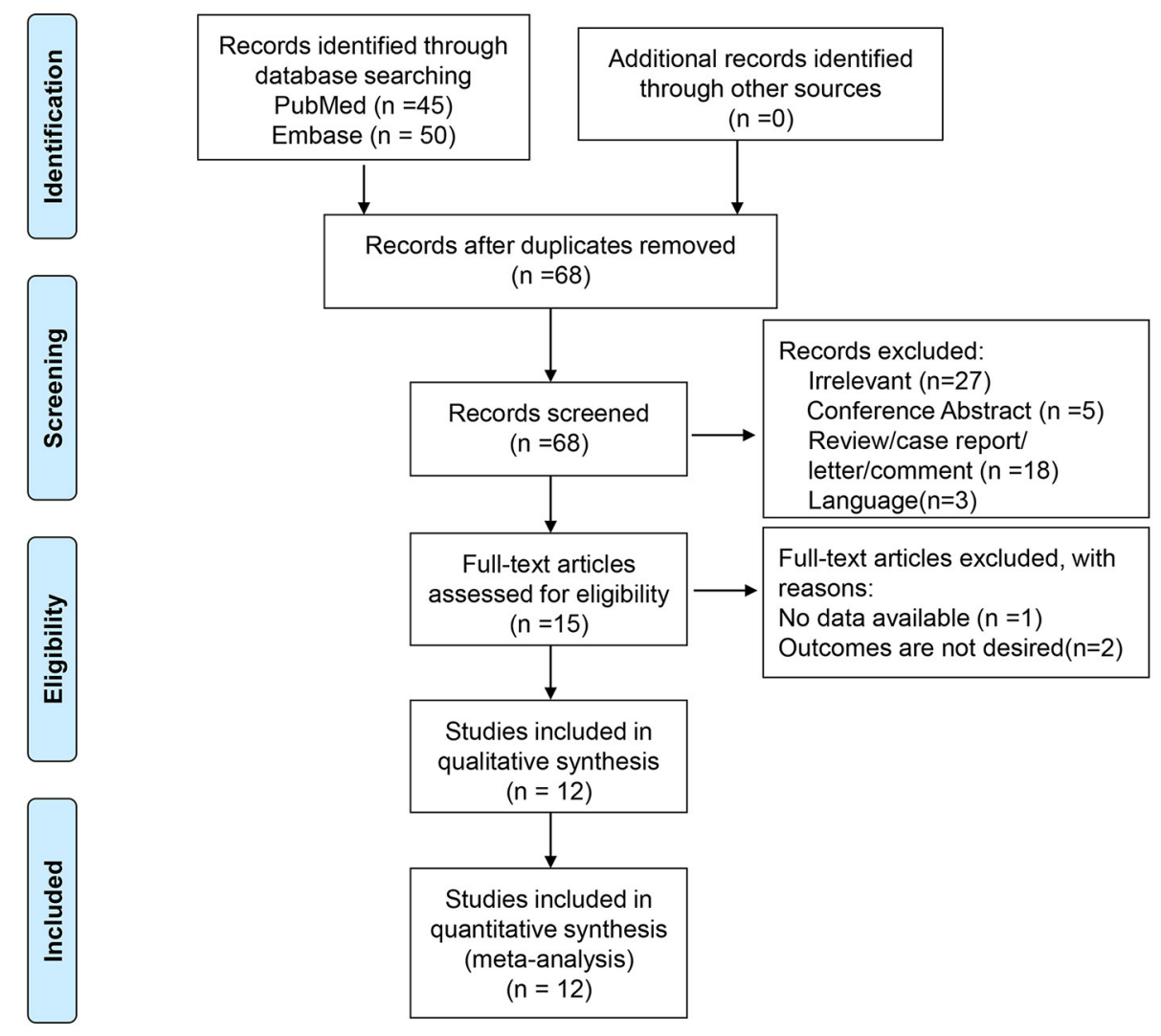

FIGURE 1 | Flowchart of study selection.

In the DCP, when considering the whole eye $6 \times 6$, amblyopia did not decrease vessel density (WMD $=-2.22$, 95\%CI: $\left.-5.86,1.42 ; I^{2}=79.6 \%, P=0.008\right)$, but a difference was observed in the whole eye $3 \times 3$ (WMD $=-1.95,95 \% \mathrm{CI}$ : $-3.23,-0.67 ; I^{2}=27.5 \%, P=0.252$ ). Vessel density was not decreased in the fovea $3 \times 3$ volume scan (WMD $=-1.20$, 95\%CI: $\left.-3.57,1.17 ; I^{2}=70.0 \%, P=0.019\right)$. When considering the parafovea, the microvessel density in the DCP was not reduced in amblyopic eyes (WMD $=-0.83$, 95\%CI: -1.99 , $0.33 ; I^{2}=31.5 \%, P=0.223$ ) (Figure 2B). In the subgroup analyses, there were no impacts of anisometropia or mixed amblyopia on microvessel density compared with healthy eyes (Supplementary Figure 1B).

\section{Foveal Avascular Zone Area in Amblyopic Eyes Compared With Healthy Control Eyes}

There was no significant difference between amblyopia eyes and healthy control eyes in foveal avascular zone area in the assumed SCP $6 \times 6$ volume scan $(\mathrm{WMD}=-0.03$, 95\%CI: $-0.08,0.01)$, assumed SCP $3 \times 3$ volume scan $\left(\mathrm{WMD}=0.01,95 \% \mathrm{CI}:-0.03,0.03 ; I^{2}=14.9 \%, P=0.319\right)$, assumed DCP $6 \times 6$ volume scan $(\mathrm{WMD}=-0.03,95 \% \mathrm{CI}$ : $-0.08,0.01)$, and in the assumed DCP $3 \times 3$ volume scan $\left(\mathrm{WMD}=0.01,95 \% \mathrm{CI}:-0.01,0.04 ; I^{2}=38.0 \%, P=0.168\right)$ (Figure 3).

\section{Foveal Thickness in Amblyopic Eyes Compared With Healthy Control Eyes}

There was no significant difference between amblyopia eyes and healthy control eyes in foveal thickness (WMD $=0.12,95 \% \mathrm{CI}$ : $\left.-8.92,9.16 ; I^{2}=66.8 \%, P=0.049\right)$ (Figure 4).

\section{Macular Vessel Density in Amblyopic Eyes Compared With Fellow Eyes}

In the SCP, amblyopia decrease the vessel density when considering the whole eye in $6 \times 6$ volume scan $\left(\mathrm{WMD}=-2.23,95 \% \mathrm{CI}:-3.62,-0.84 ; I^{2}=0.0 \%, \quad P\right.$ $=0.810)$, but not for the whole eye in $3 \times 3$ volume scan $\left(\mathrm{WMD}=-0.47,95 \% \mathrm{CI}:-1.93,0.98 ; I^{2}=62.8 \%\right.$, $P=0.068)$, fovea $3 \times 3$ (WMD $=-0.45$, 95\%CI: $\left.-3.11,2.22 ; I^{2}=40.7 \%, \quad P=0.185\right)$, and parafovea $\left(\mathrm{WMD}=-0.78,95 \% \mathrm{CI}:-3.32,1.76 ; I^{2}=69.5 \%, P=\right.$ 0.038) (Figure 5A). No differences were observed in the subgroup analyses of anisometropia and mixed amblyopia (Supplementary Figure 1C).

In the DCP, amblyopia did not decrease the vessel density when considering the whole eye in $6 \times 6$ volume scan (WMD $=-1.37,95 \% \mathrm{CI}:-3.69,0.95, I^{2}=0.0 \%, P=0.812$ ), whole eye $3 \times 3$ (WMD $=0.17,95 \% \mathrm{CI}:-0.80,1.13 ; I^{2}=52.3 \%$, $P=0.123$ ), fovea $3 \times 3$ volume scan (WMD $=-0.25$, 95\%CI: $\left.-2.04,1.54 ; I^{2}=6.3 \%, P=0.344\right)$, and parafovea 3 
TABLE 1 | The included studies.

\begin{tabular}{|c|c|c|c|c|c|c|c|c|c|c|c|}
\hline \multirow{2}{*}{$\begin{array}{l}\text { References } \\
\text { Zhang et al. } \\
(26)\end{array}$} & \multirow{2}{*}{$\begin{array}{l}\text { Design } \\
\text { Cross-sectional }\end{array}$} & \multirow{2}{*}{$\begin{array}{c}\text { Sample } \\
\text { size } \\
59\end{array}$} & \multirow{2}{*}{$\begin{array}{l}\text { Scan size } \\
6 \times 6 \mathrm{~mm}\end{array}$} & \multirow{2}{*}{$\begin{array}{c}\text { Age } \\
\begin{array}{c}\text { (years, mean } \\
\pm \text { SD) }\end{array} \\
7.86 \pm 1.88\end{array}$} & \multirow{2}{*}{$\begin{array}{c}\begin{array}{c}\text { Sex female } \\
(\%)\end{array} \\
41.0 \%\end{array}$} & \multirow{2}{*}{$\begin{array}{l}\begin{array}{l}\text { OCTA } \\
\text { algorithm }\end{array} \\
\text { RTVue XR Avanti } \\
\text { (SD) }\end{array}$} & \multirow{2}{*}{$\begin{array}{c}\begin{array}{c}\text { Spherical } \\
\text { equivalent } \\
\text { (D) }\end{array} \\
4.97 \pm 2.58\end{array}$} & \multirow{2}{*}{$\begin{array}{l}\text { Type of } \\
\text { amblyopia } \\
\text { A }\end{array}$} & \multirow{2}{*}{$\begin{array}{l}\text { Study } \\
\text { location }\end{array}$} & \multicolumn{2}{|c|}{$\begin{array}{l}\text { No. of eyes } \\
\text { intervention } \\
\text { comparator }\end{array}$} \\
\hline & & & & & & & & & & 22 & 21 \\
\hline $\begin{array}{l}\text { Chen et al. } \\
(17)\end{array}$ & $\begin{array}{l}\text { Longitudinal } \\
\text { study }\end{array}$ & 88 & $3 \times 3 \mathrm{~mm}$ & $8(7,9)$ & $59.1 \%$ & $\begin{array}{l}\text { RTVue XR Avanti } \\
\text { (SD) }\end{array}$ & $4.44 \pm 1.89$ & A & China & 22 & 66 \\
\hline $\begin{array}{l}\text { Cinar et al. } \\
\text { (18) }\end{array}$ & Cross-sectional & 74 & $3 \times 3 \mathrm{~mm}$ & $\begin{aligned} 12 & \pm 4.2 / 13 \\
& \pm 6.1\end{aligned}$ & $51.4 \%$ & Triton DRI-OCT & $3.80 \pm 2.20$ & A & Turkey & 37 & 37 \\
\hline $\begin{array}{l}\text { Gunzenhauser / } \\
\text { et al. (21) }\end{array}$ & & 12 & $3 \times 3 \mathrm{~mm}$ & 6.5 & $66.7 \%$ & $\begin{array}{l}\text { RTVue XR Avanti } \\
\text { (SD) }\end{array}$ & / & $\begin{array}{l}\text { Mixed }(A, \\
A S)\end{array}$ & USA & 12 & / \\
\hline $\begin{array}{l}\text { Wong et al. } \\
\text { (24) }\end{array}$ & Cohort & 1,075 & $6 \times 6 \mathrm{~mm}$ & $\begin{array}{l}7.57 \pm 1.20 / \\
7.65 \pm 0.97\end{array}$ & $55.4 \%$ & Triton DRI-OCT & $-0.09 \pm 4.34$ & $\begin{array}{l}\text { Mixed (A, } \\
A S)\end{array}$ & China & 30 & 1,045 \\
\hline $\begin{array}{l}\text { Yilmaz Cinar } \\
\text { and Ozkan } \\
\text { (25) }\end{array}$ & Cross-sectional & 50 & $\begin{array}{c}3 \times 3 / 6 \times \\
6 \mathrm{~mm}\end{array}$ & $\begin{array}{l}12.60 \pm 2.83 / \\
11.64 \pm 2.31\end{array}$ & $38.0 \%$ & $\begin{array}{l}\text { RTVueXR Avanti } \\
\text { (SSADA) }\end{array}$ & / & $\begin{array}{l}\text { Mixed (A, } \\
A S)\end{array}$ & Turkey & 25 & 25 \\
\hline $\begin{array}{l}\text { Araki et al. } \\
\text { (15) }\end{array}$ & Cross-sectional & 15 & $3 \times 3 \mathrm{~mm}$ & $9.8 \pm 3.4$ & $73.3 \%$ & $\begin{array}{l}\text { NIDEK RS-3000, } \\
\text { Advance (CODAA) }\end{array}$ & / & $\begin{array}{l}\text { Mixed (A, } \\
A S)\end{array}$ & Japan & 15 & / \\
\hline $\begin{array}{l}\text { Chen et al. } \\
(16)\end{array}$ & Cross-sectional & 151 & $3 \times 3 \mathrm{~mm}$ & $8 \pm 0.52$ & $45.7 \%$ & $\begin{array}{l}\text { RTVue XR } \\
\text { (AngioVue version } \\
\text { 2017.1.0.155) }\end{array}$ & $4.53 \pm 0.39$ & $\begin{array}{l}\text { Mixed (A, } \\
\text { AS) }\end{array}$ & China & 85 & 66 \\
\hline $\begin{array}{l}\text { Demirayak } \\
\text { et al. (19) }\end{array}$ & Cross-sectional & 38 & $3 \times 3 \mathrm{~mm}$ & $9.1 \pm 2.73$ & $55.3 \%$ & $\begin{array}{l}\text { RTVue XR } \\
\text { (SSADA) }\end{array}$ & $3.34 \pm 0.90$ & Mixed (A, S) & Turkey & 17 & 21 \\
\hline \multirow[t]{2}{*}{$\begin{array}{l}\text { Doguizi et al. } \\
\text { (20) }\end{array}$} & Cross-sectional & 97 & $3 \times 3 \mathrm{~mm}$ & $13.7 \pm 3.25$ & $40.2 \%$ & $\begin{array}{l}\text { RTVue XR } \\
\text { (SSADA) }\end{array}$ & $5.31 \pm 1.39$ & A & Turkey & 40 & 57 \\
\hline & & & $6 \times 6 \mathrm{~mm}$ & & & & & & & & \\
\hline $\begin{array}{l}\text { Sobral et al. } \\
\text { (23) }\end{array}$ & Cross-sectional & 26 & $3 \times 3 \mathrm{~mm}$ & $9.2 \pm 2.84$ & $53.8 \%$ & $\begin{array}{l}\text { RTVue XR } \\
\text { (SSADA) }\end{array}$ & $3.20 \pm 1.85$ & Mixed (A, S) & Portugal & 26 & 26 \\
\hline \multirow[t]{2}{*}{$\begin{array}{l}\text { Lonngi et al. } \\
\text { (22) }\end{array}$} & Case-control & 59 & $3 \times 3 \mathrm{~mm}$ & $8.0 \pm 4.0$ & $56 \%$ & $\begin{array}{l}\text { RTVue XR } \\
\text { (SSADA) }\end{array}$ & $3.86 \pm 19.88$ & Mixed $(A, S)$ & USA & 13 & 50 \\
\hline & & & $6 \times 6 \mathrm{~mm}$ & & & & & & & & \\
\hline
\end{tabular}

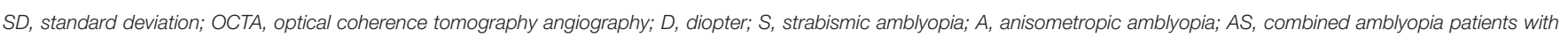
strabismus and anisometropia; SSADA, split-spectrum amplitude-decorrelation angiography algorithm; CODAA, complex OCT-signal difference analysis angiography.

TABLE 2 | Evaluation of study quality.

\begin{tabular}{|c|c|c|c|c|c|c|c|c|}
\hline References & Representativeness & Selection & Ascertainment & $\begin{array}{l}\text { Adjustment } \\
\text { for } \\
\text { confounders }\end{array}$ & $\begin{array}{l}\text { Assessment } \\
\text { of outcome }\end{array}$ & Response rate & Scores & Quality \\
\hline Chen et al. (17) & 论 & 论 & 放 & is & is & is & 7 & High \\
\hline Cinar et al. (18) & ¿ & 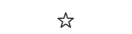 & - & 论的 & 为 & 为 & 6 & High \\
\hline Gunzenhauser et al. (21) & 认 & 约 & 认 & 论的 & औ & ఓ & 7 & High \\
\hline Yilmaz Cinar and Ozkan (25) & 放 & 放 & 战 & 计的 & is & 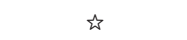 & 7 & High \\
\hline Araki et al. (15) & ఓ & - & 放 & 计的 & 认 & 乡 & 6 & High \\
\hline Chen et al. (16) & 放 & 战 & 战 & 计的 & is & 战 & 7 & High \\
\hline Demirayak et al. (19) & 战 & 岤 & 放 & 论的 & 岤 & 战 & 7 & High \\
\hline Doguizi et al. (20) & 虾 & is & is & 论的 & 为 & is & 7 & High \\
\hline
\end{tabular}

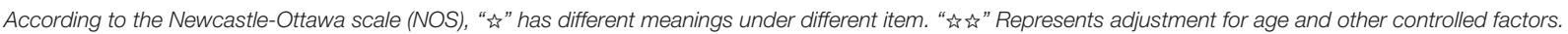

$\times 3$ volume scan $\left(\mathrm{WMD}=0.20,95 \% \mathrm{CI}:-1.76,2.16 ; I^{2}=\right.$ $44.1 \%, P=0.167$ ) (Figure 5B). No differences were observed in the subgroup analyses of anisometropia and mixed amblyopia

(Supplementary Figure 1D). 
A

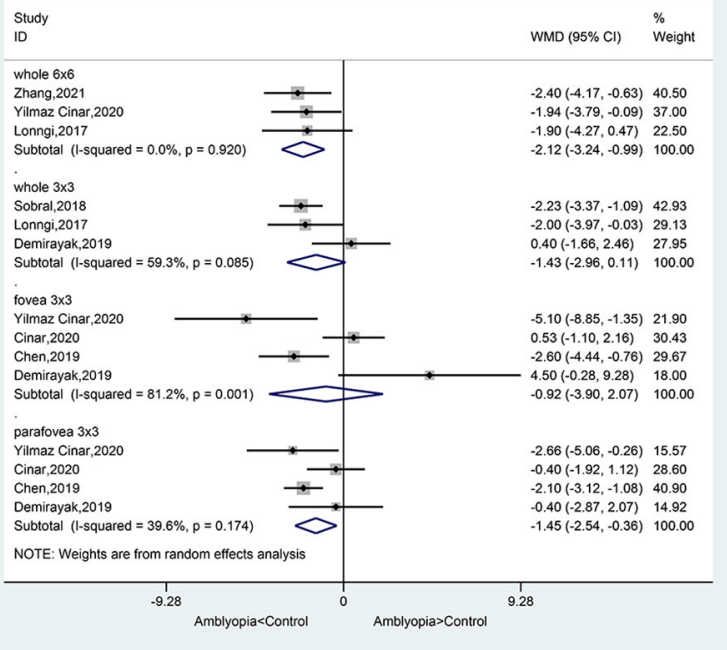

B

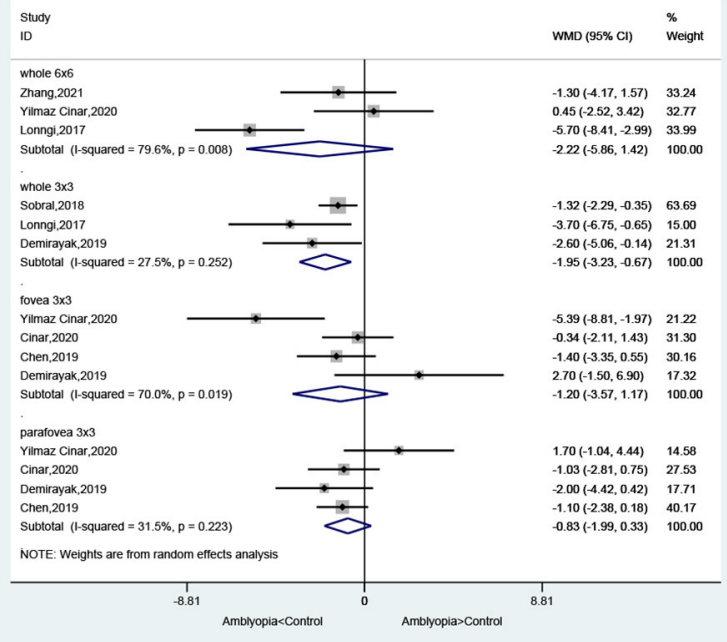

FIGURE 2 | Forest plot of macular vessel density in the superficial capillary plexus (SCP) (A) and deep capillary plexus (DCP) (B) of amblyopic eyes compared with healthy control eyes.

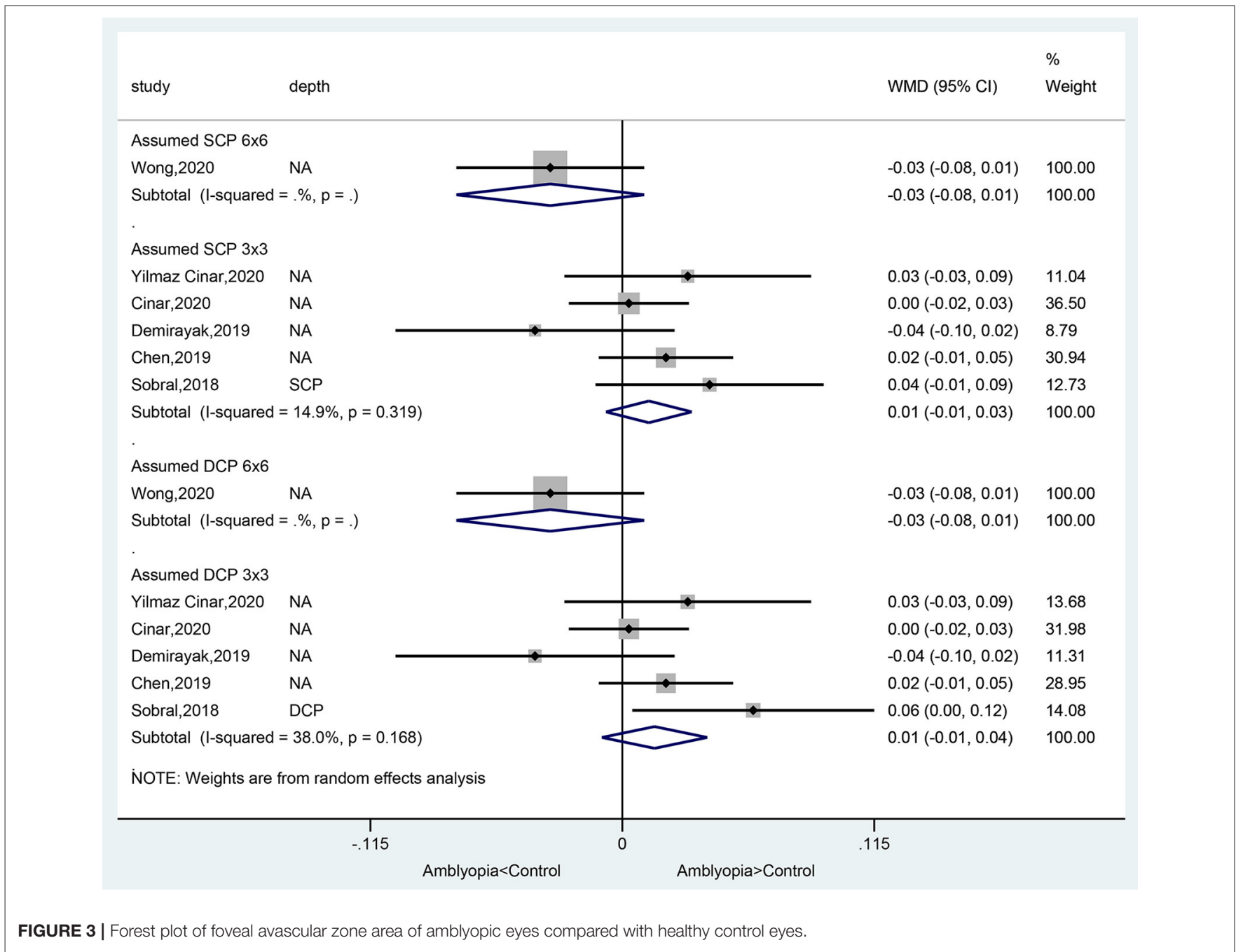




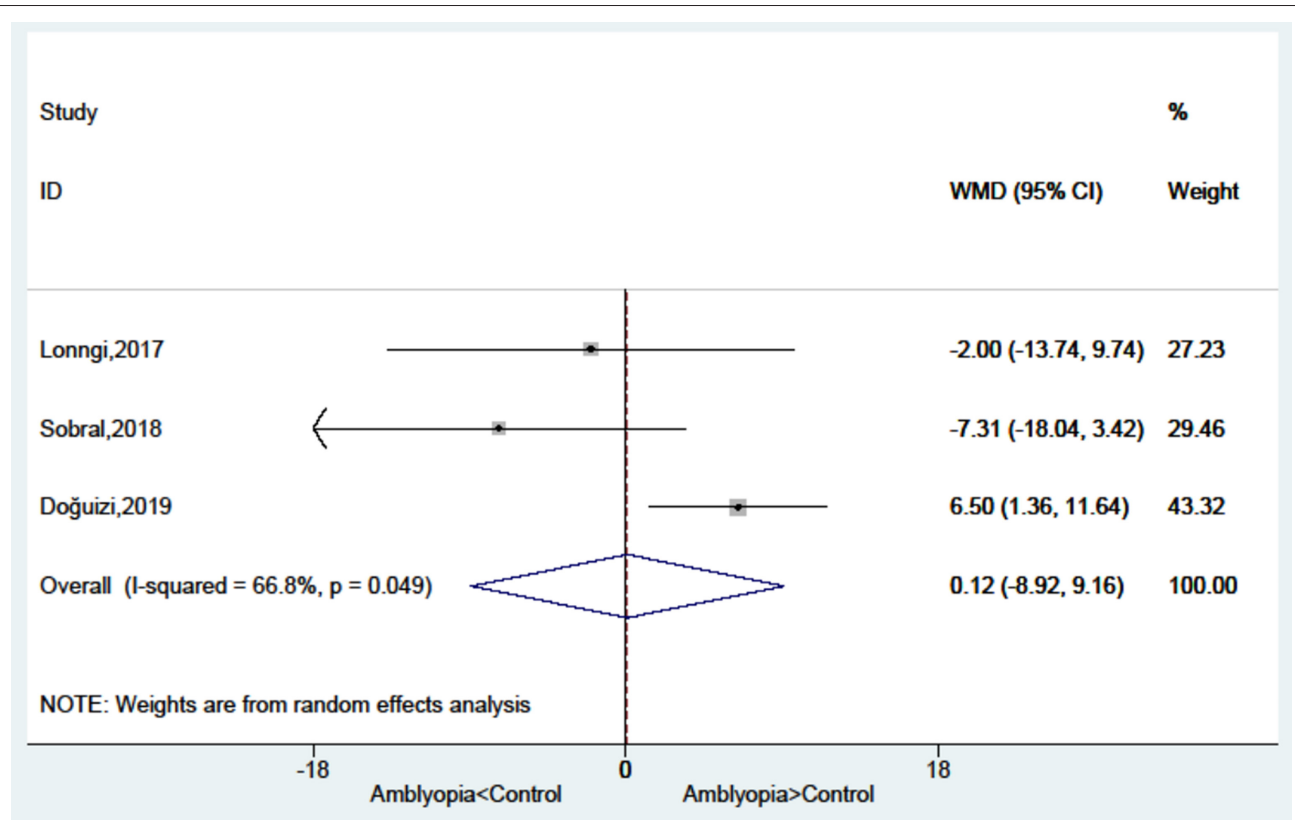

FIGURE 4 | Forest plot of the foveal thickness of amblyopic eyes compared with healthy control eyes.

A

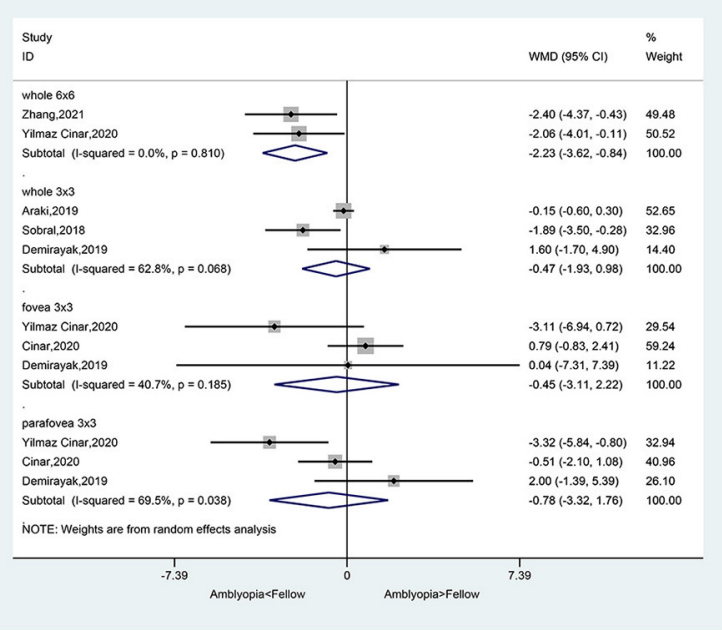

B

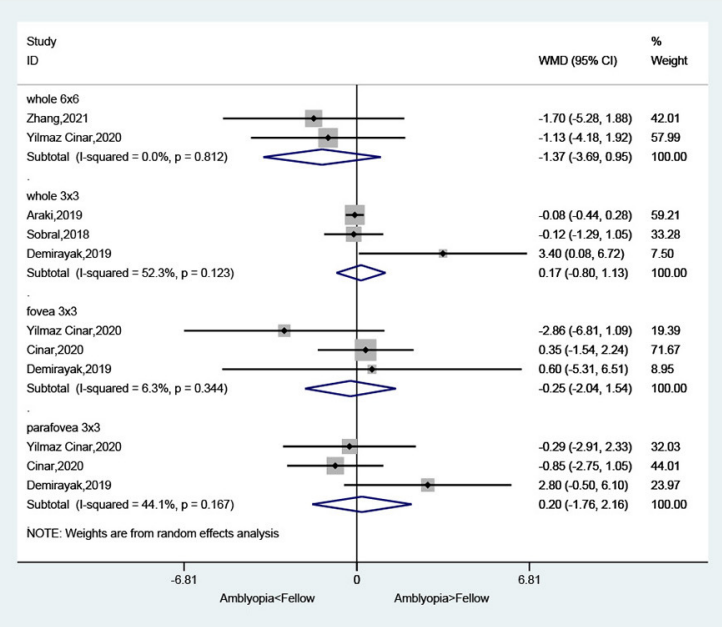

FIGURE 5 | Forest plot of macular vessel density in the superficial capillary plexus (SCP) (A) and deep capillary plexus (DCP) (B) of amblyopic eyes compared with fellow eyes.

\section{Foveal Avascular Zone Area in Amblyopic Eyes Compared With Fellow Eyes}

There was no significant difference between amblyopia eyes and fellow eyes in foveal avascular zone area in the assumed SCP $3 \times$ 3 volume scan $\left(\mathrm{WMD}=-0.01,95 \% \mathrm{CI}:-0.03,0.01 ; I^{2}=1.6 \%\right.$, $P=0.397)$ and in the assumed DCP $3 \times 3$ volume scan (WMD $=-0.00$, 95\% CI: $\left.-0.02,0.02 ; I^{2}=0.0 \%, P=0.509\right)$ (Figure 6).

\section{Foveal Thickness in Amblyopic Eyes Compared With Fellow Eyes}

There was no significant difference between amblyopia eyes and fellow eyes in foveal thickness (WMD = $\left.4.74, \quad 95 \% \mathrm{CI}:-0.66, \quad 10.14 ; \quad I^{2}=0.0 \%, \quad P=0.595\right)$ (Figure 7).

\section{Changes in Macular Vessel Density in SCP and DCP Before and After Treatments}

There were no changes in fovea $3 \times 3$ volume scan $\left(\mathrm{WMD}=-0.13,95 \% \mathrm{CI}:-2.84,2.57 ; I^{2}=0.0 \%, P=\right.$ $0.430)$ and parafovea $3 \times 3$ volume scan $(\mathrm{WMD}=-0.70$, 95\%CI: $\left.-1.99,0.58 ; I^{2}=0.0 \%, P=0.830\right)$ in the SCP (Figure 8A). There were no changes in fovea $3 \times 3$ volume scan $\left(\mathrm{WMD}=-0.84,95 \% \mathrm{CI}:-3.94,2.27 ; I^{2}=0.0 \%, P=\right.$ 0.684 ) and parafovea $3 \times 3$ volume $\operatorname{scan}(\mathrm{WMD}=-1.95$, 


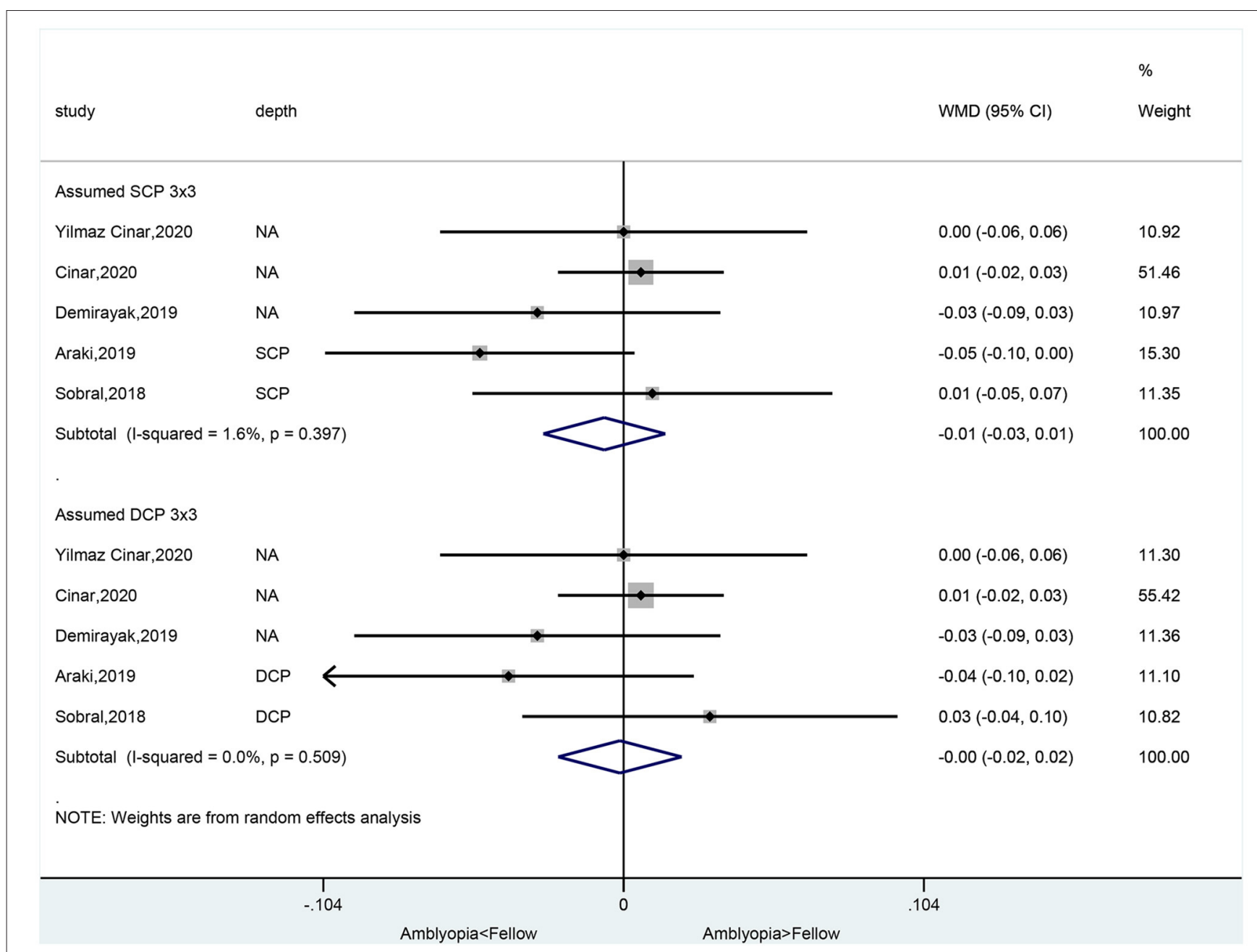

FIGURE 6 | Forest plot of foveal avascular zone area of amblyopic eyes compared with fellow eyes.

95\%CI: $\left.-4.95,1.04 ; I^{2}=56.4 \%, P=0.130\right)$ in the DCP (Figure 8B).

\section{Publication Bias}

No significant publication bias was observed (Supplementary Figure 2).

\section{DISCUSSION}

OCTA is a novel rapid and non-invasive method for the angiography of the retina and choroid $(9,10)$, but the studies yield conflicting results. Therefore, the aim of this meta-analysis was to examine the quantitative measurements of OCTA in children with amblyopia. The results indicate that according to OCTA, amblyopic eyes had lower vessel density in parafoveal SCP and DCP compared with healthy control eyes, but not compared with fellow eyes. There were no significant differences regarding the foveal avascular zone area and foveal thickness between amblyopic and non-amblyopic eyes.
Because of the small number of patients included in the previous studies, the present meta-analysis increased the power to provide a more convincing assessment of OCTA in amblyopia. Among the parameters measured by OCTA, the parafoveal vessel density was different between amblyopic and healthy control eyes, and this difference was not observed when compared with the fellow eye. This suggests that the pathogenesis of amblyopia involves a reduced vascularization of the affected eye but that this process could also be observed in the fellow normal eye. This was observed by Sobral et al. (23). Chatzistefanou et al. (27) and Meier and Giaschi (28) also observed that unilateral amblyopia affected the fellow eye and that the fellow eye cannot be considered equivalent to a normal healthy eye. Of note, different results were obtained when considering the whole eye in $6 \times 6$ and $3 \times 3$ volume scan, suggesting that different measurement methodologies affected the results.

In the present meta-analysis, no difference was observed at the fovea level between amblyopic eyes and normal healthy or fellow eyes. This is in contradiction with a meta-analysis of OCT that 


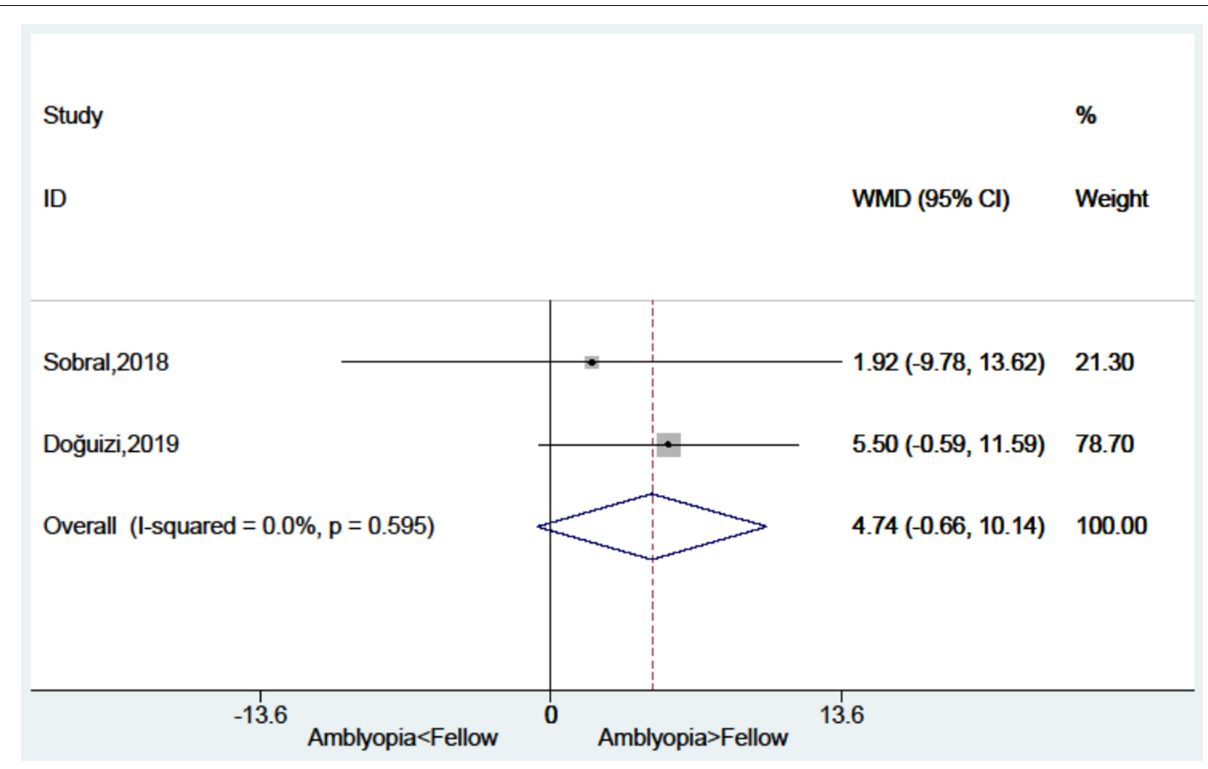

FIGURE 7 | Forest plot of the foveal thickness of amblyopic eyes compared with fellow eyes.
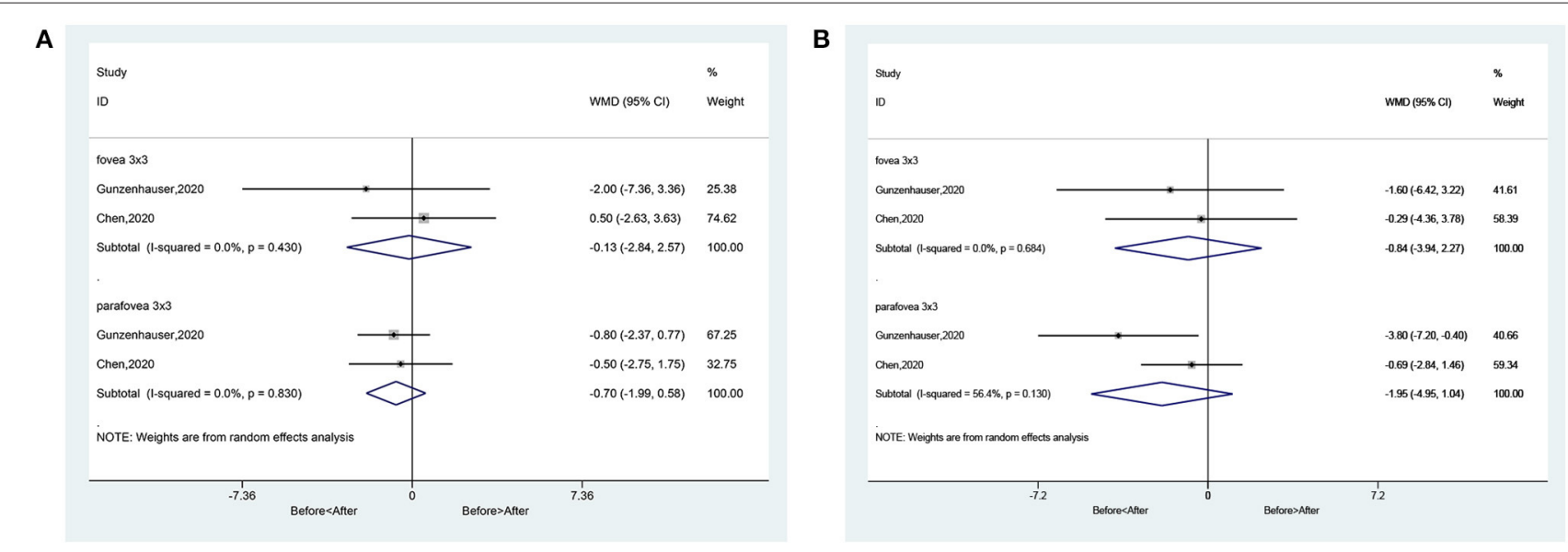

FIGURE 8 | Forest plot of macular vessel density in the superficial capillary plexus (SCP) (A) and deep capillary plexus (DCP) (B) of difference between pre-treatment and post-treatment in amblyopic eyes.

showed thicker fovea in amblyopic eyes compared with control eyes (7). This discrepancy could be due to the differences in the methods of measurement and the included studies.

Nevertheless, there is literature supporting abnormal eye development in amblyopia. Indeed, rapid visual development is observed in the sensitive visual development period, which ends by 6-7 years of age (29). During this critical period, any obstacles to the normal visual environment increase the risk of amblyopia, leading to changes in cortical neurons and their synapses (29). The blurred vision will lead to insufficient stimulation in the amblyopic eye, which affects the maturation of the macula (30), which could contribute to decreased need for oxygen supply and decreased vascularization. The lack of normal vision could also lead to reduced apoptosis of the ganglion cells in the amblyopic eyes, leading to the thicker fovea (6), as observed by $\mathrm{Li}$ et al. (7), but this was not observed in the present study.

Of course, the results of the present meta-analysis must be considered in relation to the study limitations. First, unpublished studies, conference abstracts, and non-English studies were not included. In addition, because of the small number of studies, bias might still be present. Second, because of the small number of studies, the influence of treatments could not be assessed. Such treatments have been shown to influence foveal thickness in amblyopia (31), and only two of the included studies reported treatments. Miki et al. (32) and Tugcu et al. (33) 
reported differences in foveal thickness between different types of amblyopia, but this could not be examined here. Furthermore, all included studies were cross-sectional and case-control studies, and the cause-to-effect relationship of amblyopia and reduced vascularization could not be examined. Third, the correlations between the severity of the amblyopia, the types of amblyopia, and the microvessel density of the amblyopic eyes could not be investigated because such data were not reported in the included studies. We performed subgroup analyses for the types of amblyopia, but the numbers of studies in some subgroups were small. Nevertheless, OCTA is a recent technology, the area is still being explored, and the number of studies is small. Future studies should provide additional data, especially clinical trials.

In conclusion, according to OCTA, amblyopic eyes had lower vessel density in parafoveal SCP and DCP compared with healthy control eyes, but not compared with fellow eyes. There were no significant differences regarding the foveal avascular zone area and foveal thickness between amblyopic and nonamblyopic eyes.

\section{REFERENCES}

1. Gunton KB. Advances in amblyopia: what have we learned from PEDIG trials? Pediatrics. (2013) 131:540-7. doi: 10.1542/peds.2012-1622

2. DeSantis D. Amblyopia. Pediatr Clin North Am. (2014) 61:505-18. doi: $10.1016 /$ j.pcl.2014.03.006

3. Pescosolido N, Stefanucci A, Buomprisco G, Fazio S. Amblyopia treatment strategies and new drug therapies. J Pediatr Ophthalmol Strabismus. (2014) 51:78-86. doi: 10.3928/01913913-20130107-01

4. Taylor K, Elliott S. Interventions for strabismic amblyopia. Cochrane Database Syst Rev. (2014) 7:CD006461. doi: 10.1002/14651858.CD006461.pub4

5. Potts RA, Dreher B, Bennett MR. The loss of ganglion cells in the developing retina of the rat. Brain Res. (1982) 255:481-6. doi: 10.1016/0165-3806(82)90013-X

6. Yen MY, Cheng CY, Wang AG. Retinal nerve fiber layer thickness in unilateral amblyopia. Invest Ophthalmol Vis Sci. (2004) 45:2224-30. doi: 10.1167/iovs.03-0297

7. Li J, Ji P, Yu M. Meta-analysis of retinal changes in unilateral amblyopia using optical coherence tomography. Eur J Ophthalmol. (2015) 25:400-9. doi: $10.5301 /$ ejo. 5000583

8. Fingler J, Readhead C, Schwartz DM, Fraser SE. Phase-contrast OCT imaging of transverse flows in the mouse retina and choroid. Invest Ophthalmol Vis Sci. (2008) 49:5055-9. doi: 10.1167/iovs.07-1627

9. de Carlo TE, Romano A, Waheed NK, Duker JS. A review of optical coherence tomography angiography (OCTA). Int J Retina Vitreous. (2015) 1:5. doi: 10.1186/s40942-015-0005-8

10. Gao SS, Jia Y, Zhang M, Su JP, Liu G, Hwang TS, et al. Optical coherence tomography angiography. Invest Ophthalmol Vis Sci. (2016) 57:OCT27-36. doi: 10.1167/iovs.15-19043

11. Jia Y, Morrison JC, Tokayer J, Tan O, Lombardi L, Baumann B, et al. Quantitative OCT angiography of optic nerve head blood flow. Biomed Opt Express. (2012) 3:3127-37. doi: 10.1364/BOE.3.0 03127

12. Kaizu Y, Nakao S, Arima M, Hayami T, Wada I, Yamaguchi M, et al. Flow density in optical coherence tomography angiography is useful for retinopathy diagnosis in diabetic patients. Sci Rep. (2019) 9:8668. doi: 10.1038/s41598-019-45194-z

13. Lo CK, Mertz D, Loeb M. Newcastle-Ottawa Scale: comparing reviewers' to authors' assessments. BMC Med Res Methodol. (2014) 14:45. doi: $10.1186 / 1471-2288-14-45$

\section{DATA AVAILABILITY STATEMENT}

The original contributions presented in the study are included in the article/Supplementary Material, further inquiries can be directed to the corresponding author.

\section{AUTHOR CONTRIBUTIONS}

LG, YG, and XS: substantially contributed to conception or design. LG and PZ: contributed to acquisition and analysis of data. LG: drafted the manuscript for important content and gave final approval. YG, FH, PZ, and XS: critically revised the manuscript for important intellectual content. All authors contributed to the article and approved the submitted version.

\section{SUPPLEMENTARY MATERIAL}

The Supplementary Material for this article can be found online at: https://www.frontiersin.org/articles/10.3389/fped. 2021.620565/full\#supplementary-material

14. Yeung SSY, Reijnierse EM, Pham VK, Trappenburg MC, Lim WK, Meskers CGM, et al. Sarcopenia and its association with falls and fractures in older adults: a systematic review and meta-analysis. J Cachexia Sarcopenia Muscle. (2019) 10:485-500. doi: 10.1002/jcsm.12411

15. Araki S, Miki A, Goto K, Yamashita T, Yoneda T, Haruishi K, et al. Foveal avascular zone and macular vessel density after correction for magnification error in unilateral amblyopia using optical coherence tomography angiography. BMC Ophthalmol. (2019) 19:171. doi: 10.1186/s12886-019-1177-z

16. Chen W, Lou J, Thorn F, Wang Y, Mao J, Wang Q, et al. Retinal microvasculature in amblyopic children and the quantitative relationship between retinal perfusion and thickness. Invest Ophthalmol Vis Sci. (2019) 60:1185-91. doi: 10.1167/iovs.18-26416

17. Chen W, Thorn F, Deng R, Li X, Lou J, Wang Y, et al. Macular microvasculature density changes in anisometropic amblyopic eyes after successful treatment. J Ophthalmol. (2020) 2020:8879175. doi: $10.1155 / 2020 / 8879175$

18. Cinar E, Yuce B, Aslan F, Erbakan G. Comparison of retinal vascular structure in eyes with and without amblyopia by optical coherence tomography angiography. J Pediatr Ophthalmol Strabismus. (2020) 57:48-53. doi: 10.3928/01913913-20191004-01

19. Demirayak B, Vural A, Onur IU, Kaya FS, Yigit FU. Analysis of macular vessel density and foveal avascular zone using spectral-domain optical coherence tomography angiography in children with amblyopia. J Pediatr Ophthalmol Strabismus. (2019) 56:55-9. doi: 10.3928/01913913-20181003-02

20. Doguizi S, Yilmazoglu M, Kiziltoprak H, Sekeroglu MA, Yilmazbaş P. Quantitative analysis of retinal microcirculation in children with hyperopic anisometropic amblyopia: an optical coherence tomography angiography study. J AAPOS. (2019) 23:201.e1-e5. doi: 10.1016/j.jaapos.2019.01.017

21. Gunzenhauser RC, Tsui I, Velez FG, Fung SS, Demer JL, Suh SY, et al. Comparison of pre-treatment vs. post-treatment retinal vessel density in children with amblyopia. J Binocul Vis Ocul Motil. (2020) 70:79-85. doi: 10.1080/2576117x.2020.1760695

22. Lonngi M, Velez FG, Tsui I, Davila JP, Rahimi M, Chan C, et al. Spectral-domain optical coherence tomographic angiography in children with amblyopia. JAMA Ophthalmol. (2017) 135:1086-91. doi: 10.1001/jamaophthalmol.2017.3423

23. Sobral I, Rodrigues TM, Soares M, Seara M, Monteiro M, Paiva C, et al. OCT angiography findings in children with amblyopia. J AAPOS. (2018) 22:286-9.e2. doi: 10.1016/j.jaapos.2018.03.009 
24. Wong ES, Zhang XJ, Yuan N, Li J, Pang CP, Chen L, et al. Association of optical coherence tomography angiography metrics with detection of impaired macular microvasculature and decreased vision in amblyopic eyes: the Hong Kong children eye study. JAMA Ophthalmol. (2020) 138:858-65. doi: 10.1001/jamaophthalmol.2020.2220

25. Yilmaz Cinar FG, Ozkan G. Macular capillary system and ganglion celllayer complex of the amblyopic eye with optical cohorence tomography angiography and optical cohorence tomography. Int Ophthalmol. (2020) 41:675-86. doi: 10.1007/s10792-020-01624-w

26. Zhang T, Xie S, Liu Y, Xue C, Zhang W. Effect of amblyopia treatment on macular microvasculature in children with anisometropic amblyopia using optical coherence tomographic angiography. Sci Rep. (2021) 11:39. doi: 10.1038/s41598-020-79585-4

27. Chatzistefanou KI, Theodossiadis GP, Damanakis AG, Ladas ID, Moschos $\mathrm{MN}$, Chimonidou E. Contrast sensitivity in amblyopia: the fellow eye of untreated and successfully treated amblyopes. J AAPOS. (2005) 9:468-74. doi: 10.1016/j.jaapos.2005.05.002

28. Meier K, Giaschi D. Unilateral amblyopia affects two eyes: fellow eye deficits in amblyopia. Invest Ophthalmol Vis Sci. (2017) 58:1779-800. doi: 10.1167/iovs.16-20964

29. Lewis TL, Maurer D. Multiple sensitive periods in human visual development: evidence from visually deprived children. Dev Psychobiol. (2005) 46:163-83. doi: 10.1002/dev.20055

30. Wu SQ, Zhu LW, Xu QB, Xu JL, Zhang Y. Macular and peripapillary retinal nerve fiber layer thickness in children with hyperopic anisometropic amblyopia. Int J Ophthalmol. (2013) 6:85-9. doi: 10.3980/j.issn.2222-3959.2013.01.18

31. Huynh SC, Samarawickrama C, Wang XY, Rochtchina E, Wong TY, Gole GA, et al. Macular and nerve fiber layer thickness in amblyopia: the Sydney childhood eye study. Ophthalmology. (2009) 116:1604-9. doi: 10.1016/j.ophtha.2009.03.013

32. Miki A, Shirakashi M, Yaoeda K, Kabasawa Y, Ueki S, Takagi M, et al. Retinal nerve fiber layer thickness in recovered and persistent amblyopia. Clin Ophthalmol. (2010) 4:1061-4. doi: 10.2147/opth.s13145

33. Tugcu B, Araz-Ersan B, Erdogan ET, Tarakcioglu H, Coskun C, Yigit U, et al. Structural and functional comparison of the persistent and resolved amblyopia. Doc Ophthalmol. (2014) 128:101-9. doi: $10.1007 / \mathrm{s} 10633-013-9422-\mathrm{x}$

Conflict of Interest: The authors declare that the research was conducted in the absence of any commercial or financial relationships that could be construed as a potential conflict of interest.

Copyright (c) 2021 Gao, Gao, Hong, Zhang and Shu. This is an open-access article distributed under the terms of the Creative Commons Attribution License (CC BY). The use, distribution or reproduction in other forums is permitted, provided the original author(s) and the copyright owner(s) are credited and that the original publication in this journal is cited, in accordance with accepted academic practice. No use, distribution or reproduction is permitted which does not comply with these terms. 